\title{
IMPLIKASI KEWARGANEGARAAN GANDA BAGI WARGA NEGARA INDONESIA
}

\author{
Rokilah \\ Program Studi Ilmu Hukum Universitas Serang Raya \\ Email : ilameidyfaihaazis@gmail.com
}

\begin{abstract}
Abstrak
Dalam Pasal 28D ayat (4) UUD 1945, dengan tegas dinyatakan bahwa, Setiap orang berhak atas status kewarganegaraan". Pada ketentuan tersebut tidak dinyatakan bahwa setiap orang juga berhak atas satu atau dua kewarganegaraan. Hal yang penting bagi UUD 1945 adalah tidak boleh terjadi keadaan apatride, sedangkan kemungkinan terjadinya bipatride, tidak diharuskan dan juga tidak dilarang. Hal yang penting bagi negara ialah bahwa warga negaranya itu memenuhi hak dan kewajiban sebagai warga negara. Sehingga jelas dan tegas hak dan kewajiban setiap warga negara dalam UUD 1945, hal inilah yang membedakan dengan orang asing. Keberadaan penelitian ini dimaksudkan untuk mencari jawaban terhadap permasalahan: (a) Apakah asas kewarganegaraan yang dianut oleh Negara Indonesia? (b) Bagaimana implikasi kewarganegaraan ganda bagi warga Negara Indonesia?. Untuk menemukan jawaban permasalahan tersebut ditempuh melalui metode Penelitian Hukum Normatif Empiris, yaitu penelitian yang memperhatikan bahwa hukum bekerja pada segi kaidah/norma/normwissenschaft yaitu perundang-undangan yang berkaitan dengan kewarganegaraan Republik Indonesia, yang tidak terlepas dari unsur sosial/empiris. Hasil penelitian menunjukkan bahwa: (1) Indonesia menganut asas kewarganegaraan, yaitu Ius soli, ius sanguinis, asas kewarganegaraan tunggal dan asas kewarganegaraan rangkap terbatas. (2) Hak dan kewajiban warga negara tercantum dalam UUD 1945, hal tersebut menimbulkan implikasi bahwa warga negara Indonesia yang memiliki status kewarganegaraan ganda juga mempunyai hak, kewajiban dan partisipasi dalam negara yang sama dengan warga negara asli Indonesia, asalkan mereka ketika berusia 18 tahun harus memilih kewarganegaraan Indonesia.
\end{abstract}

\section{Kata Kunci: Implikasi, Kewarganegaraan ganda, Warga Negara, Indonesia}

\section{LATAR BELAKANG MASALAH}

Kenyataan yang berlaku umum bahwa untuk berdirinya negara yang merdeka harus dipenuhi beberapa unsur pembentuk. Unsurunsur pembentuk tersebut ada yang bersifat mutlak atau konstitutif, dan ada pula yang bersifat tambahan atau deklaratif. Unsur pertama merupakan syarat mutlak, sehingga apabila unsur satu saja tidak ada, negara pun tidak ada. Adapun unsur-unsur negara yang termasuk kategori ini, dalam rumusan Konvensi Montevidio tahun 1933, terdiri atas tiga unsur penting, yakni rakyat, wilayah, dan pemerintah yang berdaulat. Sementara unsur tambahan adalah pengakuan dari negaranegara lain.
Tanpa adanya wilayah yang pasti, tidak mungkin suatu negara dapat berdiri, dan begitu pula adalah mustahil untuk menyatakan adanya negara tanpa rakyat yang tetap. Di samping itu, meskipun kedua syarat wilayah (territory) dan rakyat telah dipenuhi, apabila pemerintahannya bukan pemerintahan yang berdaulat yang bersifat nasional, belumlah dapat dinamakan negara tersebut suatu negara yang merdeka.

Rakyat sebagai sekumpulan manusia yang hidup di suatu tempay yang dilawankan dengan makhluk-makhluk lain yang hidup di dunia. Beberapa istilah yang erat pengertiannya dengan rakyat ialah, rumpun (ras), bangsa (volks), dan nazi (natie). 
Rumpun diartikan sebagai sekumpulan manusia yang merupakan suatu kesatuan karena mempunyai ciri-ciri jasmaniah yang sama. Ciri-ciri jasmaniah itu misalnya, warna kulit, warna rambut, bentuk badannya, bentuk mukanya dan sebagainya. Sedangkan bangsa, diartikan sebagai sekumpulan manusia yang merupakan suatu kesatuan karena mempuyai perasaan kebudayaan, misalnya, bahasa, adat kebiasaan, agama dan sebagainya. Sementara nazi, juga sering disebut bangsa, akan tetapi mempuyai ciri-ciri yang berbeda. Natie diartikan sebagai sekumpulan manusia yang merupakan suatu kesatuan karena mempunyai kesatuan politik yang sama. Setelah diuraikan arti rumpun, bangsa, dan nazi, maka rakyat itu mempunyai arti yang netral, dan rakyat sebagai salah satu unsur daripada negara harus dihubungkan dengan ikatannya dengan negara, karena itu rakyat harus dimaksudkan sebagai warga negara yang dibedakan dengan orang asing.

Rakyat (people) yang menetap di suatu wilayah tertentu, dalam hubungannya dengan negara disebut warga negara (citizen). Warga negara secara sendiri-sendiri merupakan subjek-subjek hukum yang menyandang hakhak dan sekaligus kewajiban-kewajiban dari dan terhadap negara. setiap warga negara mempunyai hak-hak yang wajib diakui (recognized) oleh negara dan wajib dihormati (respected), dilindungi (protected), dan difasilitasi (facilitated), serta dipenuhi (fulfilled), oleh negara. Sebaliknya, setiap warga negara juga mempunyai kewajibankewajiban kepada negara yang merupakan hak-hak negara yang juga wajib diakui (recognized), dihormati (respected), dan ditaati atau ditunaikan (complied) oleh setiap warga negara.

Pengertian Warga Negara menurut Kamus Besar Bahasa Indonesia (KBBI) (2002) adalah penduduk sebuah negara atau bangsa berdasarkan keturunan, tempat kelahiran, dan sebagainya, yang mempunyai kewajiban dan hak penuh sebagai seorang warga dari negara itu. Sementara Dr. A. S Hikam (2000 mendefinisikan Warga Negara (citizenship) adalah anggota dari sebuah komunitas yang membentuk itu sendiri. Warga negara dari suatu negara merupakan pendukung dan penanggung jawab kemajuan dan kemunduran suatu negara. oleh sebab itu, seseorang yang menjadi anggota atau warga suatu negara haruslah ditentukan oleh Undang-Undang yang dibuat oleh negara tersebut. Sebelum negara menentukan siapasiapa yang menjadi warga negara, terlebih dahulu negara harus mengakui bahwa setiap orang berhak memilih kewarganegaraan, memilih tempat tinggal di wilayah negara dan meninggalkannya serta berhak kembali sebagaimana dinyatakan oleh Pasal 28E ayat (1) UUD 1945. Pernyataan ini mengandung makna bahwa orang-orang yang tinggal dalam wilayah negara dapat diklasifikasikan menjadi:

1) Penduduk, yaitu orang-orang yang memiliki domisili atau tempat tinggal tetap di wilayah negara itu, yang dapat dibedakan warga negara dan Warga Negara Asing (WNA).

2) Bukan penduduk, yaitu orang-orang asing yang tinggal dalam negara bersifat sementara sesuai dengan visa yang diberikan oleh negara (kantor imigrasi) yang bersangkutan, seperti turis.

Persoalan kewarganegaraan ini juga penting dipandang dari sudut hukum Internasional. Seperti dikatakan oleh A.W. Bradley dan K.D. Ewing, nasionalitas dan status kewarganegaraan itu menghubungkan seseorang dengan orang lain dalam pergaulan di dunia Internasional. Oleh karena di zaman modern sekarang, perkembangan dinamika hubungan antarnegara sangat terbuka, maka hubungan antara satu negara dengan dunia Interanasional tidak dapat dihindari. Karena itu, dalam setiap wilayah negara akan selalu ada warga negara sendiri dan orang asing atau warga negara asing, yang kesemuanya samasama disebut penduduk. Artinya, tidak semua penduduk suatu negara merupakan warga negara, karena mungkin saja dia adalah orang asing. Dengan demikian, penduduk suatu negara dapat dibagi dua yaitu warga negara 
dan orang asing. Keduanya mempunyaai kedudukan yang berbeda dalam berhubungan dengan negara (state). Warga negara (citizen) mempunyai hubungan yang tidak ter'putus' walaupun yang bersangkutan berdomisili di luar negeri, asalkan yang bersangkutan tidak memutus sendiri kewarganegaraannya. Sementara itu, orang asing hanya mempunyai hubungan dengan negara selama ia bertempat tinggal di wilayah negara yang bersangkutan. Selama itu, adalah merupakan kewajiban negara untuk melindungi kepentingan setiap penduduk yang ada di dalam wilayah negaranya.

Istilah kewarganegaraan memiliki arti yang menunjukkan hubungan atau ikatan antara negara dan warga negara. Kewarganegaraan diartikan segala jenis hubungan dengan suatu negara yang mengakibatkan adanya kewajiban negara itu untuk melindungi orang yang bersangkutan. Adapun menurut Undang-Undang Nomor 12 Tahun 2006 tentang Kewarganegaraan Republik Indonesia, Kewarganegaraan adalah segala hal-ihwal yang berhubungan dengan warga negara. Pengertian kewarganegaraan dibedakan menjadi empat, yaitu; 1) Kewarganegaraan dalam arti yuridis ditandai dengan adanya ikatan hukum antara orangorang dengan negara. 2) Kewarganegaraan dalam arti sosiologis ditandai dalam ikatan emosional. 3) Kewarganegaraan dalam arti formil menunjukkan pada tempat kewarganegaraan itu berdomisili. 4) Kewarganegaraan dalam arti materil menunjukkan pada akibat hukum dari status kewarganegaraan, yaitu adanya hak dan kewajiban warga negara.

Pada praktiknya ada kecenderungan yang memungkinkan seseorang memiliki kewarganegaraan rangkap (bipatride) atau sebaliknya, tidak memiliki kewarganegaraan (apatride). Kewarganegaraan rangkap ini disebabkan dianutnya asas yang berbeda di atara dua negara dalam menentukan kewarganegaraannya. Negara yang satu menggunakan asas ius sanguinis dan yang lain menggunakan asas ius soli. Bahkan dalam perkembangannya di kemudian hari, timbul pula kebutuhan baru berdasarkan pengalaman di berbagai negara bahwa kedua asas tersebut harus diubah dengan asas yang lain atau harus diterapkan secara bersamaan untuk mencegah kemungkinan terjadinya keadaan double-citizenship atau dwikewarganegaraan (bipatride) atau sebaliknya sama sekali berstatus tanpa kewarganegaraan (apatride). Namun demikian, dalam praktik, ada pula negara yang justru menganut keduaduanya karena pertimbangan lebih menguntungkan bagi kepentingan negara yang bersangkutan. Sistem inilah yang biasa dinamakn sebagai asas campuran. Asas yang dipakai bersifat campuran sehingga dapat menyebabkan apatride atau bipatride. Dalam hal demikian, yang ditoleransi biasanya adalah keadaan bipatride, yaitu dwikewarganegaraan.

Di dunia dewasa ini cenderung semakin menyatu dan dengan dinamika pergaulan antarumat manusia yang semakin longgar dan dinamis, gejala kewarganegaraan ganda ini sangat mungkin akan terus berkembang di masa-masa yang akan datang. Bahkan, boleh jadi, yang akan muncul dalam praktik, tidak saja masalah dwikewarganegaraan, tetapi mungkin juga-multi kewarganegaraan, terutama di kalangan kelompok orang yang kaya dan dapat hidup berpindah-pindah dengan sekehendak hatinya. Bagi mereka itu, tidak juga kerugian apa-apa bagi negara mana pun untuk membiarkan mereka memiliki status kewarganegaraan lebih dari satu, asalkan yang bersangkutan tetap menjalankan kewajibannya untuk membayar pajak sesuai dengan ketentuan perundang-undangan negara yang bersangkutan. Oleh karena itu, semua negara modern di dunia dewasa ini dihadapkan pada persoalan kewarganegaraan ganda ini sebagai masalah yang riel. Hal yang penting bagi negara ialah bahwa warga negaranya itu memenuhi kewajibannya sebagai warga negara. Bahwa ia tetap ingin bertahan dengan 
dua kewarganegaraan, dapat saja tidak dipandang sebagai kerugian negara. ${ }^{1}$

Memperhatikan uraian tersebut di atas maka penulis tertarik untuk mengadakan penelitian yang kemudian hasilnya dituangkan dalam laporan penelitian dengan judul : "Implikasi Kewarganegaraan Ganda bagi warga Negara Indonesia".

\section{RUMUSAN MASALAH}

Berdasarkan uraian latar belakang masalah di atas, maka dapat dirumuskan masalah, sebagai berikut:

a. Apakah asas kewarganegaraan yang dianut oleh Negara Indonesia?

b. Bagaimana implikasi kewarganegaraan ganda bagi warga Negara Indonesia?

\section{METODE PENELITIAN}

Penelitian mengenai "Implikasi Kewarganegaran Ganda bagi warga Negara Indonesia." merupakan Penelitian Hukum Normatif Empiris, yaitu penelitian yang memperhatikan bahwa hukum bekerja pada segi kaidah/norma/normwissenschaft yaitu perundang-undangan yang berkaitan dengan kewarganegaraan Republik Indonesia, yang tidak terlepas dari unsur sosial/empiris yaitu kenyataan adanya implikasi kewarganegaraan ganda bagi warga Negara Indonesia sehingga perlu diketahui pelindungannya sesuai tujuan penelitian.

Adapun pendekatan dalam penelitian yaitu mengenai berlakunya hukum positif. ${ }^{2}$ Yaitu berlakunya perundang-undangan Kewarganegaraan Republik Indonesia yang relevan dengan permasalahan kewarganegaraan ganda di Indonesia dengan cara melakukan analisa/analisis terhadap data hukum dan hasil yang diperoleh dalam penelitian dengan cara mengetahui makna yang dikandung oleh istilah-istilah yang digunakan dalam peraturan perundangundangan secara konsepsional, sekaligus mengetahui masalah-masalah yang terjadi

\footnotetext{
${ }^{1}$ Jimly Asshiddiqie, op.cit., hlm 392-393.

2 Soerjono Soekanto, Pengantar Penelitian Hukum, Jakarta: UI Press, 1999, hlm. 80.
}

dalam penerapan/pelaksanaan serta pendaftaran kewarganegaraan.

Sumber Data yang digunakan dalam penelitian ini adalah sumber data sekunder, yaitu data yang diambil dari sumber kedua atau data pustaka, dalam wujud bahan hukum primer, bahan hukum sekunder dan bahan tersier. ${ }^{3}$ Teknik pengumpulan data dilakukan dengan cara studi pustaka (library research) yakni studi terhadap dokumen-dokumen yang relevan dengan penelitian di perpustakaan. ${ }^{4}$ Data yang diperoleh melalui penelitian pustaka selanjutnya dijadikan sebagai data penunjang sehingga akan terjawab sesuai dengan permasalahan yang sedang dihadapi. Dalam mengumpulkan, mengolah dan menganalisis data digunakan pendekatan kualitatif dengan sifat interaktif koleksi data atau pengumpulan data dengan analisis data. Analisis data dilakukan secara kualitatif. Keseluruhan data yang relevan dengan tujuan penelitian dianalisis secara kualitatif, yakni dengan abstraksi dan interpretasi yang mendalam, dengan mengacu pada teori-teori yang membangun kerangka pemikiran. Setiap proses ini dilakukan dengan mengacu pada tujuan penelitian. Seluruh tahapan analisis ini menghasilkan rumusan yang tersusun dalam bentuk uraian yang deskriptif. Di dalam penelitian kualitatif, menekankan pada deskripsi secara alami atas fenomena yang dilakukan dari keadaan yang sewajarnya. ${ }^{5}$

\section{LANDASAN TEORI}

Asas kewarganegaraan diperlukan untuk mengatur status kewarganegaraan seseorang. Hal ini penting agar seseorang mendapatkan perlindungan hukum dari negara, serta menerima hak dan kewajibannya. Ketentuan tentang status kewarganegaraan penting diatur dalam

\footnotetext{
${ }^{3}$ Bambang Waluyo, Penelitian Hukum dalam Praktek, Jakarta: Sinar Grafika, 1996, hlm. 57

4 Suharsini Arikunto, Prosedur Penelitian, Jakarta: Rineka Cipta, 2002, hlm 117.

5 Beni Ahmad Saebani, 2008, Metode Penelitian Hukum, Bandung: Pustaka Setia, 2008, hlm. 101.
} 
peraturan perundangan dari negara. Peraturan perundangan inilah yang kemudian dijadikan asas untuk penentuan status kewarganegaraan seseorang. Setiap warga negara memiliki budaya, sejarah, dan tradisi yang berbeda satu sama lain. Dalam asas kewarganegaraan dalam Undang-Undang Nomor 12 Tahun 2006 tentang Kewarganegaraan Republik Indonesia, dikenal dua pedoman yaitu: (1) asas kewarganegaraan umum, dan (2) asas kewarganegaraan khusus. ${ }^{6}$

Setiap negara mempunyai kebebasan dan kewenangan untuk menentukan asas kewarganegaraan. Dalam asas kewarganegaraan dikenal dua pedoman, yaitu sebagai berikut: ${ }^{7}$

1. Asas kelahiran (Ius Soli) adalah penentuan status kewarganegraan berdasarkan tempat atau daerah kelahiran seseorang. Pada awalnya asas kewarganegaraan hanyalah ius soli saja. Hal tersebut sebagai suatu anggapan bahwa jika seseorang lahir di suatu wilayah negara, otomatis dan logis ia menjadi warga negara tersebut.

2. Asas keturunan (Ius Sanguinis) adalah pedoman kewarganegaraan berdasarkan pertalian darah atau keturunan.

Mengenai soal kewarganegaraan, masing-masing negara menganut asas yang menguntungkan, dan lainnya adalah campuran dari kedua asas itu. Asas campuran adalah asas yang menentukan kewarganegaraan lebih dari satu atau asas tersebut sekaligus diperlakukan. Karena masing-masing menganut asas yang menguntungkan bagi kepentingan politiknya, maka perbedaaan asas ini tidak jarang membawa kesulitan-kesulitan dalam hubungan Internasional. Kesulitan-kesulitan ini dapat membawa akibat seorang memperoleh kewarganegaraan lebih dari satu

6 Srijanti, A. Rahman H.I dan Purwanto, op.cit, hlm. 68-69.

7 Heri Herdiawato \& Jumanta Hamdayama, Cerdas, Kritis, dan Aktif Berwarganegara: Pendidikan Kewarganegaraan untuk Perguruan Tinggi, Jakarta: Erlangga, 2010, hlm 58. (dwikewarganegaraan) dan seorang menjadi tidak berkewenangan sama sekali (apatride). ${ }^{8}$ Dalam problem status kewarganegaraan seseorang terjadi apabila asas kewarganegaraan di atas diterapkan secara tegas dalam sebuah negara, akan mengakibatkan status kewarganegaraan seseorang menjadi sebagai berikut: ${ }^{9}$

a. Apatride, yaitu seseorang tidak mendapat kewarganegaraan disebabkan oleh orang tersebut lahir di sebuah negara yang menganut ius sanguinis.

b. Bipatride, yaitu seseorang akan mendapatkan dua kewarganegaraan, apabila orang tersebut berasal dari orang tua yang mana negaranya menganut ius sanguinis, sedangkan dia lahir di suatu negara yang menganut ius soli.

c. Multipatride, yaitu seseorang yang memiliki lebih dari dua kewarganegaraan, yaitu seseorang (penduduk) yang tinggal di perbatasan antara dua negara.

Untuk memecahkan problem kewarganegaraan di atas, setiap negara memiliki peraturan sendiri-sendiri yang prinsip-prinsipnya bersifat universal, sebagaimana dinyatakan dalam UUD 1945 pasal 28D ayat (4), bahwa setiap orang berhak atas status kewarganegaraan. Oleh karena itu negara Indonesia melalui Undang-Undang Nomor 62 Tahun 1958 tentang Kewarganegaraan Indonesia dinyatakan bahwa cara memperoleh kewarganegaraan Indonesia adalah; 1) karena kelahiran, 2) karena pengangkatan, 3) karena dikabulkan permohonan, 4) karena pewarganegaraan, 5) karena perkawinan, 5) karena turut ayah dan ibu, dan 7) karena pernyataan.

Untuk mengatasi masalah kewarganegaraan, maka Indonesia mengatur tata cara memperoleh kewarganegaraan Indonesia dalam Undang-Undang Nomor 62

${ }^{8}$ Moh. Kusnadi \& Bintan R. Saragih, op.cit., hlm. 110-111.

${ }^{9}$ Syahrial Syarbaini, Pendidikan Pancasila, Implementasi Nilai-Nilai Karakter Bangsa di Perguruan Tinggi, Bogor: Ghalia Indonesia, 2012, hlm. 262-263. 
Tahun 1958 dan diperbaharui dalam UndangUndang Nomor 12 Tahun 2006, dimana ada delapan cara memperoleh kewarganegaraan yang tercantum dalam Pasal 9 UndangUndang Nomor 12 Tahun 2006, meliputi: a). telah berusia 18 (delapan belas) tahun atau sudah kawin; b). pada waktu mengajukan permohonan sudah bertempat tinggal di wilayah negara Republik Indonesia paling singkat 5 (lima) tahun berturut-turut atau paling singkat 10 (sepuluh) tahun tidak berturut-turut; c). sehat jasmani dan rohani; d). dapat berbahasa Indonesia serta mengakui dasar negara Pancasila dan Undang-Undang Dasar Negara Republik Indonesia Tahun 1945; e). tidak pernah dijatuhi pidana karena melakukan tindak pidana yang diancam dengan pidana penjara 1 (satu) tahun atau lebih; f). jika dengan memperoleh Kewarganegaraan Republik Indonesia, tidak menjadi berkewarganegaraan ganda; g). mempunyai pekerjaan dan/atau berpenghasilan tetap; dan $\mathrm{h}$ ). membayar uang pewarganegaraan ke Kas Negara.

Menurut Pasal 4 Undang-Undang Nomor 12 Tahun 2006 tentang Kewarganegaraan Republik Indonesia, yang dimaksud dengan Warga Negara Indonesia adalah: a). setiap orang yang berdasarkan peraturan perundang-undangan dan/atau berdasarkan perjanjian Pemerintah Republik Indonesia dengan negara lain sebelum Undang-Undang ini berlaku sudah menjadi Warga Negara Indonesia; b). anak yang lahir dari perkawinan yang sah dari seorang ayah dan ibu Warga Negara Indonesia; c). anak yang lahir dari perkawinan yang sah dari seorang ayah Warga Negara Indonesia dan ibu warga negara asing; d). anak yang lahir dari perkawinan yang sah dari seorang ayah warga negara asing dan ibu Warga Negara Indonesia; e). anak yang lahir dari perkawinan yang sah dari seorang ibu Warga Negara Indonesia, tetapi ayahnya tidak mempunyai kewarganegaraan atau hukum negara asal ayahnya tidak memberikan kewarganegaraan kepada anak tersebut; f). anak yang lahir dalam tenggang waktu 300 (tiga ratus) hari setelah ayahnya meninggal dunia dari perkawinan yang sah dan ayahnya Warga Negara Indonesia; g). anak yang lahir di luar perkawinan yang sah dari seorang ibu Warga Negara Indonesia; h). anak yang lahir di luar perkawinan yang sah dari seorang ibu warga negara asing yang diakui oleh seorang ayah Warga Negara Indonesia sebagai anaknya dan pengakuan itu dilakukan sebelum anak tersebut berusia 18 (delapan belas) tahun atau belum kawin; i). anak yang lahir di wilayah negara Republik Indonesia yang pada waktu lahir tidak belas status kewarganegaraan ayah dan ibunya; j). anak yang baru lahir yang ditemukan di wilayah negara Republik Indonesia selama ayah dan ibunya tidak diketahui; k). anak yang lahir di wilayah negara Republik Indonesia apabila ayah dan ibunya tidak mempunyai kewarganegaraan atau tidak diketahui keberadaannya; 1). anak yang dilahirkan di luar wilayah negara Republik Indonesia dari seorang ayah dan ibu Warga Negara Indonesia yang karena ketentuan dari negara tempat anak tersebut dilahirkan memberikan kewarganegaraan kepada anak yang bersangkutan; $\mathrm{m}$ ). anak dari seorang ayah atau ibu yang telah dikabulkan permohonan kewarganegaraannya, kemudian ayah atau ibunya meninggal dunia sebelum mengucapkan sumpah atau menyatakan janji setia.

Warga negara merupakan salah satu unsur hakiki dan unsur pokok suatu negara. Status kewarganegaraan menimbulkan hubungan timbal balik antara warga negara dan negaranya. Setiap warga negara mempunyai hak dan kewajiban terhadap negaranya. Sebaliknya, negara mempunyai kewajiban memberikan perlindungan terhadap, warga negaranya. Sementara itu warga negara menurut UUD 1945 pasal 26 ayat (1) ialah orang-orang bangsa Indonesia asli dan orang-orang bangsa lain yang disahkan dengan undang-undang sebagai warga negara, sedangkan menurut UndangUndang Nomor 62 Tahun 1958 tentang Kewarganegaraan Republik Indonesia 
menyatakan bahwa warga Negara Republik Indonesia adalah orang-orang yang berdasarkan perundang-undangan yang berlaku sejak Proklamasi 17 Agustus 1945 sudah menjadi warga negara Republik Indonesia.

\section{PEMBAHASAN}

Berdasarkan pertimbangan, perlu dibentuk undang-undang kewarganegaraan yang baru sebagai pelaksanaan Pasal 26 ayat (3) Undang-Undang Dasar Negara Republik Indonesia Tahun 1945 yang mengamanatkan agar hal-hal mengenai warga negara dan penduduk diatur dengan undang-undang. Untuk memenuhi tuntutan masyarakat dan melaksanakan amanat Undang-Undang Dasar 1945 sebagaimana tersebut di atas, UndangUndang Kewarganegaraan Republik Indonesia ini memperhatikan asas-asas kewarganegaraan umum atau universal, yaitu asas ius sanguinis, ius soli, dan campuran. Adapun asas-asas yang dianut dalam UndangUndang Kewarganegaraan Republik Indonesia ini sebagai berikut:

1. Asas ius sanguinis (law of the blood) adalah asas yang menentukan kewarganegaraan seseorang berdasarkan keturunan, bukan berdasarkan negara. tempat kelahiran.

2. Asas ius soli (law of the soil) secara terbatas adalah asas yang menentukan kewarganegaraan seseorang berdasarkan negara tempat kelahiran, yang diberlakukan terbatas bagi anak-anak sesuai dengan ketentuan yang diatur dalam Undang-Undang ini.

3. Asas kewarganegaraan tunggal adalah asas yang menentukan satu kewarganegaraan bagi setiap orang.

4. Asas kewarganegaraan ganda terbatas adalah asas yang menentukan kewarganegaraan ganda bagi anak-anak sesuai dengan ketentuan yang diatur dalam Undang-Undang ini.

Pada dasarnya Negara Indonesia tidak mengenal kewarganegaraan ganda (bipatride) ataupun tanpa kewarganegaraan (apatride).
Adapun kewarganegaraan ganda yang diberikan kepada anak dalam Undang-Undang kewarganegaraan Republik Indonesia ini merupakan suatu pengecualian. Selain asas tersebut di atas, beberapa asas khusus juga menjadi dasar penyusunan Undang-Undang tentang Kewarganegaraan Republik Indonesia, antara lain sebagai berikut:

1. Asas kepentingan nasional adalah asas yang menentukan bahwa peraturan kewarganegaraan mengutamakan kepentingan nasional Indonesia, yang bertekad mempertahankan kedaulatannya sebagai negara kesatuan yang memiliki cita-cita dan tujuannya sendiri.

2. Asas perlindungan maksimum adalah asas yang menentukan bahwa pemerintah wajib memberikan perlindungan penuh kepada setiap Warga Negara Indonesia dalam keadaan apapun baik di dalam maupun di luar negeri.

3. Asas persamaan di dalam hukum dan pemerintahan adalah asas yang menentukan bahwa setiap Warga Negara Indonesia mendapatkan perlakuan yang sama di dalam hukum dan pemerintahan.

4. Asas kebenaran substantif adalah prosedur. pewarganegaraan seseorang tidak hanya bersifat administratif, tetapi juga disertai substansi dan syarat-syarat permohonan yang dapat dipertanggungjawabkan kebenarannya.

5. Asas nondiskriminatif adalah asas yang tidak membedakan perlakuan dalam segala hal ikhwal yang berhubungan dengan warga negara atas dasar suku, ras, agama, golongan, jenis kelamin dan gender.

6. Asas pengakuan dan penghormatan terhadap hak asasi manusia adalah alas yang dalam segala hal ikhwal yang berhubungan dengan warga negara harus menjamin, melindungi, dan memuliakan hak asasi manusia pada umumnya dan hak warga negara pada khususnya.

7. Asas keterbukaan adalah asas yang menentukan bahwa dalam segala hal ihwal yang berhubungan dengan warga negara harus dilakukan secara terbuka. 
8. Asas publisitas adalah asas yang menentukan bahwa seseorang yang memperoleh atau kehilangan Kewarganegaraan Republik Indonesia diumumkan dalam Berita Negara Republik Indonesia agar masyarakat mengetahuinya.

Dalam literatur hukum dan dalam praktik, dikenal adanya tiga asas kewarganegaraan, yaitu asa ius soli, ius sanguinis, dan asas campuran. Dari ketiga asas itu, yang dianggap sebagai asas yang utama ialah asas ius soli dan ius sanguinis. Sehubungan dengan kedua asas tersebut, setiap negara bebas memilih asas yang hendak dipakai dalam rangka kebijakan kewarganegaraannya untuk menentukan siapa saja yang diterima sebagai warga negara dan siapa yang bukan warga negara. Oleh karena itu, di berbagai negara, dapat timbul berbagai pola pengaturan yang tidak sama di bidang kewarganegaraan. Bahkan, antara satu dengan negara lain dapat timbul pertentangan atau conflict of law atau pertentangan hukum. Dalam hal itu akan menimbulkan persoalan bipatride atau dwi-kewarganegaraan, atau sebaliknya menyebabkan apatride, yaitu keadaan tanpa kewarganegaraan sama sekali. Bipatride atau dwi-kewarganegaraan timbul ketika menurut peraturan-peraturan tentang kewarganegaraan dari berbagai negara, seseorang sama-sama dianggap sebagai warga negara oleh negara-negara yang bersangkutan. ${ }^{10}$

Pada umumnya, baik bipatride maupun apatride adalah keadaan yang tidak disukai baik oleh negara di mana orang tersebut berdomisili, maupun oleh yang bersangkutan sendiri. Keadaan bipatride membawa ketidakpastian dalam status seseorang, sehingga dapat saja merugikan negara tertentu ataupun bagi yang bersangkutan itu sendiri. Ada juga negara yang tidak menganggap hal ini sebagai persoalan sehingga menyerahkan saja kebutuhan untuk memilih kewarganegaraan itu kepada orang yang bersangkutan. Di

\footnotetext{
${ }^{10}$ Jimly Asshiddiqie, op.cit., hlm 386-213.
}

kalangan negara-negar yang sudah makmur, dan rakyatnya sudah rata-rata berpenghasilan tinggi, tidak dirasakan adanya kerugian apapun bagi negara untuk mengakui statusdwi kewarganegaraan itu. Akan tetapi, di negara-negara yang sedang berkembang, yang penduduknya masih terbelakang, keadaan bipatrie iu sering dianggap lebih banyak merugikan. Sebaliknya keadaan apatride juga membawa akibat bahwa orang tersebut tidak akan mendapat perlindungan dari negara manapun juga. ${ }^{11}$

Baik bipatride maupun apatride tersebut tentu harus dihindarkan dengan cara menutup kemungkinan terjadinya kedua keadaan itu dengan Undang-Undang Kewarganegaraan. Dalam Undang-Undang Kewarganegaraan Republik Indonesia, siapa saja yang termasuk orang-orang dengan status kewarganegaraan ganda, yaitu, dijelaskan dalam Pasal 6 ayat 1, bahwa terhadap anak berakibat memiliki kewarganegaraan ganda sebagaimana dimaksud dalam Pasal 4 huruf (c) anak yang lahir dari perkawinan yang sah dari seorang ayah Warga Negara Indonesia dan ibu warga negara asing; huruf (d). anak yang lahir dari perkawinan yang sah dari seorang ayah warga negara asing dan ibu Warga Negara Indonesia; huruf h). anak yang lahir di luar perkawinan yang sah dari seorang ibu warga negara asing yang diakui oleh seorang ayah Warga Negara Indonesia sebagai anaknya dan pengakuan itu dilakukan sebelum anak tersebut berusia 18 (delapan belas) tahun atau belum kawin; huruf i). anak yang lahir di wilayah negara Republik Indonesia yang pada waktu lahir tidak belas status kewarganegaraan ayah dan ibunya.

Apabila seseorang menjadi warga negara suatu negara, maka orang tersebut mempunyai hak dan kewajiban. Hak adalah suatu yang seharusnya diperoleh oleh warga negara setelah melaksanakan segala sesuatu yang menjadi kewajibannya sebagai warga negara. Undang-Undang Dasar Negara Republik Indonesia Tahun 1945, memberikan 
perlindungan baik kepada setiap peduduk maupun setiap warga negara Republik Indonesia. Artinya, UUD 1945 juga menjamin perlindungan bagi setiap penduduk tanpa melihat apakah dia warga negara atau orang asing. Misalnya, Pasal 29 ayat (2) UUD 1945 menentukan, "Negara menjamin kemerdekaan tiap-tiap penduduk untuk memeluk agamanya masing-masing dan untuk beribadat menurut agamanya dan kepercayaannya itu”. Hal ini menunjukkan bahwa negara memang menjamin akan memberikan perlindungan dalam masalah agama terhadap setiap penduduk atau setiap orang yang ada dan hidup di wilayah Negara Kesatuan Republik Indonesia, dengan tidak melihat apakah ia warga negara atau orang asing.

Di bagian lain dari UUD 1945 ditentukan pula adanya hak-hak yang secara khusus dijamin untuk warga negara (the citizens' rights). Ini berarti bahwa setiap warga negaralah yang berhak penuh atas halhal yang berkaitan dengan kesempatan yang diberikan negara kepada warga negaranya, hak mana kemudian dapat dituntut oleh warga negara. Hak warga negara Indonesia dalam UUD 1945 adalah:

a. Pasal 6 ayat (1): Calon Presiden dan calon wakil Presiden harus seorang warga negara indonesia sejak kelahirannya dan tidak pernah menerima kewarganegaraan lain karena kehendaknya sendiri, tidak pernah mengkhianati negara, serta mampu secara rohani dan jasmani untuk melaksanakan tugas dan kewajiban sebagai Presiden dan wakil Presiden.

b. Pasal 27 ayat (2): Tiap-tiap warga negara berhak atas pekerjaan dan penghidupan yang layak bagi kemanusiaan.

c. Pasal 28D ayat (3): Setiap warga negara berhak memperoleh kesempatan yang sama dalam pemerintahan.

d. Pasal 31 ayat (1): Setiap warga negara berhak mendapat pendidikan.

Ketentuan hak-hak tersebut di atas khusus bagi warga negara Indonesia baik sejak lahir maupun anak yang memiliki kewarganegaraan ganda, dan pada akhirnya setelah berusia, 18 (delapan belas) tahun atau sudah kawin anak tersebut harus menyatakan memilih salah satu kewarganegaraannya, yaitu menjadi warga negara Indonesia. Adapun kewajiban warga negara Indonesia dalam UUD 1945 ialah:

a. Pasal 27 ayat (1): Segala warga negara bersamaan kedudukannya di dalam hukum dan pemerintahan dan wajib menjunjung hukum dan pemerintahan itu dengan tidak ada kecualinya.

b. Pasal 27 ayat (3): Setiap warga Negara berhak dan wajib ikut serta dalam upaya pembelaan Negara.

c. Pasal 30 ayat (1): Tiap-tiap warga negara berhak dan wajib ikut serta dalam usaha pertahanan dan keamanan negara.

d. Pasal 31 ayat (2): Setiap warga negara wajib mengikuti pendidikan dasar dan pemerintah wajib membiayainya.

\section{KESIMPULAN}

Berdasarkan uraian permasalahan tersebut di atas, maka dapat diuraikan kesimpulan sebagai berikut:

a. Asas-asas yang dianut dalam UndangUndang Nomor 12 Tahun 2006 tentang Kewarganegaraan Republik Indonesia, untuk menentukan kewarganegaran seseorang warga negara Indonesia dikenal beberapa asas yang dianut oleh Indonesia, yaitu: asas ius soli, ius sanguinis, asas kewarganegaraan tunggal dan asas kewarganegaraan ganda terbatas.

b. Implikasi kewarganegaraan ganda bagi warga negara Indonesia terletak pada hak dan kewajiban yang ditanggung oleh setiap warga negara. Dalam penelitan ini fokus kepada siapa saja yang termasuk kedalam warga negara Indonesia sehingga jelas dan tegas hak dan kewajiban yang disandingkan kepada warga negara yang bersangkutan, meskipun status kewarganegaran tersebut rangkap karena satu dan lain hal, tetapi yang berkepentingan masih tinggal dalam Negara Kesatuan Republik Indonesia atau 
di luar wilayah Negara Kesatuan Republik Indonesia. Hak warga negara tercantum dalam UUD 1945 terdapat dalam Pasal 6 ayat 1 , Pasal 27 ayat 2 , Pasal $28 \mathrm{D}$ ayat 3 dan Pasal 31 ayat 1 . Sementara berkenaan dengan kewajiban warga negara tertuang dalam UUD 1945 mencakup Pasal 27 ayat 1, Pasal 27 ayat 3, Pasal 30 dan Pasal 31 ayat 2 .

\section{DAFTAR PUSTAKA}

\section{Buku-Buku}

Bambang Waluyo, Penelitian Hukum dalam Praktek, Jakarta: Sinar Grafika, 1996.

Beni Ahmad Saebani, Metode Penelitian Hukum, Bandung: Pustaka Setia, 2008.

Deddy Ismatullah \& Asep A. Sahid Gatara Fh, Ilmu Negra: Dalam Multiperspektif Kekuasaan, Masyarakat, Hukum, dan Agama, Bandung: Pustaka Setia, 2017.

Hamid Darmadi , Urgensi Pendidikan Pancasila dan Kewarganegaraan di Perguruan Tinggi, Bandung: Alfabeta, 2013.

Heri Herdiawato \& Jumanta Hamdayama, Cerdas, Kritis, dan Aktif Berwarganegara: Pendidikan Kewarganegaraan untuk Perguruan Tinggi, Jakarta: Erlangga, 2010.
Jimly Asshiddiqie, Pengantar Ilmu Hukum Tata Negara, Jakarta: Rajawali Pers, 2012.

Moh. Kusnadi \& Bintan R. Saragih, Ilmu Negara, Jakarta: Gaya Media Pratama, 2008.

Soerjono Soekanto, Pengantar Penelitian Hukum, Jakarta: UI Press, 1999.

Suharsini Arikunto, Prosedur Penelitian, Jakarta: Rineka Cipta, 2002.

Srijanti, dkk, Pendidikan Kewarganegaraan untuk Mahasiswa, Yogyakarta: Graha Ilmu, 2009.

Syahrial Syarbaini, Pendidikan Pancasila, Implementasi Nilai-Nilai Karakter Bangsa di Perguruan Tinggi, Bogor: Ghalia Indonesia, 2012.

\section{Peraturan Perundang-undangan}

Undang-Undang Dasar Negara Republik Indonesia Tahun 1945.

Undang-Undang Nomor 62 Tahun 1958 tentang Kewarganegaraan Republik Indonesia. LN 1958/113; TLN NO. 1647.

Undang-Undang Republik Indonesia Nomor 12 Tahun 2006 tentang Kewarganegaraan Republik Indonesia. Tambahan Lembaran Negara Republik Indonesia Nomor 4634. 